\section{DIGITAL COMMONS \\ @ UNIVERSITY OF SOUTH FLORIDA}

\section{ABO: Interactive Journal for Women in the Arts, 1640-1830}

Volume 1

Issue 1 Volume 1 (2011): Women's Poetry

Article 2

2011

\title{
Anna Seward and the Sonnet: Milton's Champion
}

Claudia Thomas Kairoff

Wake Forest University, kairofct@wfu.edu

Follow this and additional works at: https://digitalcommons.usf.edu/abo

Part of the Dramatic Literature, Criticism and Theory Commons, Educational Methods Commons, Feminist, Gender, and Sexuality Studies Commons, and the Literature in English, British Isles Commons

\section{Recommended Citation}

Kairoff, Claudia Thomas (2011) "Anna Seward and the Sonnet: Milton's Champion," ABO: Interactive Journal for Women in the Arts, 1640-1830: Vol.1: Iss.1, Article 2.

http://dx.doi.org/10.5038/2157-7129.1.1.1

Available at: https://digitalcommons.usf.edu/abo/vol1/iss1/2

This Scholarship is brought to you for free and open access by Digital Commons @ University of South Florida. It has been accepted for inclusion in ABO: Interactive Journal for Women in the Arts, 1640-1830 by an authorized administrator of Digital Commons @ University of South Florida. For more information, please contact digitalcommons@usf.edu. 


\section{Anna Seward and the Sonnet: Milton's Champion}

\section{Keywords}

1790s, Anna Seward, Charlotte Smith, Romanticism, sensibility, sonnet, women's poetry

Creative Commons License

(c) (i) $\Theta$

This work is licensed under a Creative Commons Attribution-No Derivative Works 3.0 License. 
Two hundred years after their publications captivated the British reading public, Charlotte Smith's Elegiac Sonnets (1784-1811) and Anna Seward's Original Sonnets on Various Subjects (1799) are generally regarded as landmarks in the late eighteenth-century sonnet revival. ${ }^{1}$ But while both poets are usually mentioned in discussions of this phenomenon, Smith has recently been honored as the chief influence on her romantic successors, and probably the better poet of the two. Smith's influence is unquestionable; the latter claim, arguable. Because we view both poets in the aftermath of the romantic triumph, we tend to adopt a teleological view of literary history that values poets according to how closely they approximate or anticipate the romantics. Smith's self-referential emphasis, persistent melancholia, and vaunted uniqueness echo throughout Coleridge's and Wordsworth's poems and down through Byron's. Seward, measured against Smith's proto-romantic qualities, is judged the lesser poet. But by measuring Seward against Smith, we ignore Seward's adherence to well-established principles and her development of the aesthetics of sensibility. At times, her sonnets argue critical opinions or contemplate moral insights drawn from her correspondence, but almost every sonnet, regardless of theme, illustrates Seward's preference for poetry that connects the self to others and to the surrounding world rather than emphasizing, as Smith does, the individual's isolation. Seward conducted her campaign against Smith in the guise of Milton's champion, defending his sonnets' form and occasional topics as the models for her own. By studying Seward's defense of the Miltonic or "legitimate” sonnet, we can recover the ways her favored sonnet form supported and advanced her beliefs about the function of poetry, the role of the poet, and why Smith's approach to the sonnet involved stakes so high that Seward vehemently condemned Smith's sonnets.

Hailed as “Britannia's Muse” after her first publication, an Elegy on Captain Cook (1780), Seward maintained her reputation with a timely Monody on Major André (1781) and a stream of poems, including sonnets, and critical pieces throughout the 1780s and 1790s. In the Gentleman's Magazine, a biographical notice published the month after her death in 1809 concludes that "As an Authoress, few women have exhibited more strength of intellect, or more genuine delicacy of taste, than Miss Seward. Her poetry is particularly distinguished by beauty of imagery, and vigour of sentiment” (“Biographical Sketch” 379). Based on contemporary estimates, Seward's late-century publication of her collected sonnets merit an argument defending their excellence. In Eighteenth-Century Women Poets and Their Poetry, however, Paula R. Backscheider has made a strong case for Smith's preeminence. Responding to critics, including Seward, who have accused Smith of literary infractions ranging from monotony to plagiarism, Backscheider explains that Smith constructed the most challenging form of sonnet sequence, the chain, in which tones, images, and other repetitions create variations on a single theme (328). Where Seward found “everlasting lamentables,”(“Letter LXXI” 3: 287) Backscheider praises Smith for composing a suite of poems on "the great mood of the poetry of her century” (326). Petrarch, Shakespeare, Spenser, and other predecessors had written similar cycles on the topic of love; Smith, Backscheider shrewdly perceives, applied the same organization and techniques to melancholy. She also argues that Smith's copious echoes of other poets should never have been described as plagiarism. Smith's sonnets' intertextuality performs numerous functions, such as distinguishing the speaker from Smith herself and incorporating the moods and themes of predecessors into her poems (Backscheider 335-38).

Backscheider's argument echoes those of other recent commentators who have explored Smith's artfulness and the sources of her appeal to contemporaries. ${ }^{2}$ Susan Staves's opinion that Smith's 
Elegiac Sonnets were "the most important volume of women's poems of this period" (i.e., the later century) now seems nearly indisputable (396). The widespread appeal of a volume that went through nine editions in Smith's lifetime, combined with her sonnets' rich texture, leads inexorably to the question: why did Seward find these poems so objectionable? It is difficult to find a recent critical discussion of Elegiac Sonnets that does not quote Seward's opinion of them as "everlasting lamentables" and "hackneyed scraps of dismality" ("Letter LXXI" 2: 287). ${ }^{3}$ An avid student of English poetry-she once explained her self-confidence as the result of "having made the grace, harmony, and elegance of the English language [her] long and particular study..." ("Letter XXVIII” 2: 140)—why did Seward fail to recognize Smith's claims to excellence? Backscheider concludes with several other critics that Seward's response was chiefly that of a competitor and notes that Elizabeth Robinson also adopted a combative tone when introducing her own sonnets (340-41). But Seward's dismissive attitude seems extreme, even if she was defending her title as "Britannia’s Muse.” If Smith’s sonnets were so execrable, why did Seward hammer away at them in letter after letter, damning them to her correspondents (especially those who admired Smith's verse) while admitting that she had read only the first of many successively expanding editions? In this article, I will consider the reasons propelling Seward's dislike of Smith's sonnets and her competing vision of sonnet excellence. I will argue that Seward contributed to the sonnet renaissance a unique version descended from Milton's model but refined according to principles, such as the sonnet's appropriate tone and topics, she claimed to derive from his. Because Seward's ideas and inspirations are now less accessible than Smith's, her volume has not received a comparable degree of attention: I hope to restore the social and aesthetic stakes of her sonnet interventions.

Seward's adamant belief that the only true or "legitimate" sonnets were patterned on those of Petrarch and Milton had been publicly expressed by 1788, when she augmented Henry Cary's slim volume of sonnets with two prefatory sonnets lauding his poetic promise. ${ }^{4}$ The first sonnet praises Cary for adhering to the "strict energic measures" of the Petrarchan sonnet instead of daring to "lawless assume" the name of sonnet for a lesser form (lines 12, 5). In a letter to William Haley, Seward confessed that her sonnet was intended to combat Smith's assertion, in the preface to her first edition, "that the legitimate sonnet is not suited to the genius of our language” (“Letter LIII” 2: 222-23).

Smith was not the only poet whose verse attracted Seward's passionate criticism. Gillen D'Arcy Wood has recently interrogated the vehemence of Seward's "Remonstrance," a poetic rebuke of William Cowper's disapproval, mentioned in The Task, of the grandiose Handel

Commemoration in 1784. Wood refrains from dismissing Seward as ill-tempered or injudicious due to her vehement response to a "rather mild objection" not to Handel's music but to the composer's near-deification by throngs assembled in Westminster Abbey to hear his choral compositions (455-56). Instead, Wood perceives the outlines of a larger dispute in Cowper's and Seward's disparate opinions. In Cowper, Wood argues, Seward recognized the beginnings of a movement away from the notion of art as communal and sociable and toward the romantic conception of art as the product of solitary observers usually critical of their surroundings. In Wood's view, Seward was astute in perceiving that Cowper's innocuous-seeming refusal to join in the universal adulation of her beloved Handel indicated rejection, in essence, of her beliefs about the purpose of art and the role of the artist. Handel had become a figure in Britain's pantheon, not unlike Shakespeare and Milton, and his oratorios, in particular, were acclaimed by 
national consensus as part of the fabric of British culture. Poets maintained a central role by guiding public taste toward appreciation of their cultural heritage. To Seward, dissenters from Handelomania encouraged a factional approach to culture and, ultimately, to national identity (456-57). Cherishing her personal reputation as British Muse and shunning what she considered the vicious critics sponsored by London review journals, Seward would certainly have found Cowper's remarks critically heretical and even unpatriotic. Sensing the threat to her beliefs about culture - indeed, to her world-view_-she responded brutally to lines that now seem unexceptionable.

I agree with Wood's thesis about Seward's conception of art's function and the role of the artist. He correctly refuses to dismiss "Remonstrance," perceiving instead that it reveals Seward's distress when her values were undermined not just by Cowper but by increasing numbers of critics, writers, and readers. Wood's argument, and especially his approach, provides guidance for any writer attempting to escape the simplistic conclusions typical of much previous Seward criticism. Her reiterated diatribes against Smith can all too easily be mocked as the result of jealousy, critical arrogance, or misguided taste rather than as her defense of principles threatened by emergent romantic values. It is more rewarding, however, to pursue Seward's reasons for dismissing the Elegiac Sonnets on the assumption that her vehemence indicates deep-seated literary-cultural antagonism rather than injured self-importance. Wood discovered a complicated network of associations beneath Seward's remark about Cowper, including her fear that art and artists would lose status if no longer revered as the sustainers of their culture but regarded instead as its maverick critics. Her fear regarding Cowper's attitude proved justifiable, although art gained a different kind of status as a result of its ascendancy. Is Seward then to be denigrated because she failed to predict the consequences of the romantic rebellion? Because what Wood describes as her performative, sociable ideal of art lost ground to the cult of the lonely, prophetic wanderer? Because sensibility transformed into romanticism?

Seward might instead be viewed as among the last adherents to principles that dominated western artistic thinking for many centuries, from the bards who declaimed epics in the royal courts to the bluestockings who hosted chamber music and poetry readings in their parlors. Backscheider refers to her as "one of the last neoclassicists" for "maintaining the English ability to master and then improve a respected form” (343). Seward would also have insisted upon the limits after which improvement became desecration, a conservative position that was under attack in many guises during the radical conclusion of the century. In Relationships of Sympathy, Thomas J. McCarthy has explained that "for Romantic readers, the emphasis on feeling in language led to their tendency to approach the written word as speech.... As a result they presumed that the feelings, experiences, and events in a work of literature were those of the author himself" (40).

McCarthy argues that literary emphasis on "the inner life of feeling” predominated after 1800, "rather than social attitudes or opinions" (148). If McCarthy is correct, Seward and like-minded peers were fighting a losing battle in upholding a sonnet ideal that emphasized technical virtuosity and encouraged topics such as social commentary. While it would consequently be impossible to reinstate Seward's theories, there is more to be gained from reconstructing her positions than from dismissing them. In view of our current fascination with the roots of romanticism, it is not surprising that Seward is sometimes overlooked. She resisted the onset of 
romanticism even as she helped popularize some of its characteristic forms, such as the ode and the sonnet; its insistence on the relationship between the human consciousness and the landscape; its reverence for Shakespeare, Milton, and the English poets. Wood located some crucial distinctions between Seward's and the romantics' point of view. Might we glean from Seward's reaction against Smith some further insights into the romantics' break with their predecessors, however closely the latter anticipated the former? Might we even glean renewed appreciation of Seward's sonnets when we understand what was at stake in their composition?

James L. Clifford and Teresa Barnard have revealed the extent to which Seward edited her personal correspondence for future publication. ${ }^{5}$ Seward's correspondence is nevertheless a faithful guide to her theories about the sonnet. Since she revised her letters in the decade following publication of her sonnet collection, they probably constitute her final, posthumous campaign on behalf of her sonnet principles. From her many statements, it is clear that Seward did not view herself solely as Smith's adversary. Alert to what Paula Feldman, Daniel Robinson, and others have called a sonnet revival, she demanded a leading role not only in promoting that movement but in guiding public judgment about what constituted sonnet excellence. As Feldman, Robinson, Backscheider and others observe, Seward and Smith were but two of a number of poets publishing their sonnets, each aware of his or her peers and eager to claim preeminence. Seward seems to have viewed Smith as the head of a party disputing the sanctity of a particular form, the so-called legitimate sonnet. By using that term, Seward announced her intention to enter a lively public debate over what might properly be considered a sonnet and which techniques produced admirable sonnets. Reviewed in isolation, Seward's remarks appear repetitive, pompous, even shrewish. But in the context of public discussion, her argument adopts contemporary terminology to argue a recognized position. As Backscheider notes, Mary Robinson similarly glanced at Smith in the introduction to her sonnet sequence Sappho and Phaon (1796), complaining like Seward about poets who take liberties with the form's conventions (341). Sandro Jung has described the sonnets of Susanna Pearson, a working-class Sheffield poet, as Petrarchan both in form and in their departure from Smith's hopelessness. By the time Seward distinguished her sonnets from "those minute Elegies of twelve alternate rhymes, closing with a couplet, which assume the name of Sonnet,"(Original Sonnets iii) her covert reference to Smith must have been palpable, but she was also participating in a wellknown controversy in which Smith represented the opposing side. Like a politician campaigning for office, Seward "stayed on point" throughout her epistolary and published remarks, amplifying rather than changing her argument throughout. ${ }^{6}$ As we survey the main points of her discourse, we must ponder the cultural stakes for which she thought herself fighting by defending the correct form of a relatively late poetic form that, until recently, had been considered minor.

Seward unfailingly invoked Milton as the model for succeeding authors of English sonnets. Milton had patterned his sonnets on those of Petrarch, imitating his characteristic structure and rhyme scheme. In her preface, Seward quotes an article in the Gentleman's Magazine (1786) by her cousin Henry White, whose opinions suspiciously parallel her own. (For various reasons, Seward sometimes employed White to publish her views. ${ }^{7}$ ) White explains that the sonnet "partakes of the nature of Blank Verse, by the lines running into each other at proper intervals" (qtd. in Original Sonnets iv). White added that although the rhymes of the octet are invariable, those of the sestet might be varied. The concluding couplet was optional. Perhaps Seward was 
recalling White's article when, in 1789, she suggested to Mary Knowles that the sonnet is "the intermediate style of poetry, between rhyme and blank verse; and the undulating and varied pauses of the latter, give to the true sonnet an air of graceful freedom, beyond that of all other measures - though . . . it is in reality the most difficult" ("Letter LIV" 2: 226). White pronounced Milton's sonnets "the great models of perfection" (qtd. in Original Sonnets iv), and Seward likewise confessed to Knowles that she was "enamoured of the legitimate Miltonic sonnet" ("Letter LIV" 2: 226). Seward and Robinson were among many poets who named Milton as their exemplar. Curiously, the deference accorded Milton ignored the sonnet achievements of Surrey, Sidney, Shakespeare, Spenser, and others who composed significant sequences with rhyme schemes more conducive to the English language due to the concluding octave's additional pair of rhymes. How had Milton's sonnets superseded his predecessors' to the degree that theirs were considered bastard efforts, unworthy of what Seward calls “our National Poetry” (Original Sonnets v)?

The answer to this question parallels the disagreement between Seward and Cowper that Wood found so revealing. As Jonathan Brody Kramnick has demonstrated, Milton was a relative newcomer to the British pantheon in Seward's lifetime. ${ }^{8}$ Kramnick argues that Spenser and Milton were elevated in the mid-eighteenth century not because, like Shakespeare, they were believed to be universally appealing, but because they required the guidance of trained scholars and professional critics (42-43, 103-104). Thus, their recognition supported not only British national identity but its entire print culture and all who labored to create it. Seward and her generation would have grown up believing not only in Milton's excellence but in his difficulty, which in turn granted elite status to those capable of explicating his texts and techniques. Seward often extolled Shakespeare as England's greatest dramatic poet, but she ignored his other poetry. Assuming, like most contemporaries, that Shakespeare was poorly educated, she would not have regarded as authoritative his choice to adopt a less rigorous rhyme scheme for his sonnets. On the other hand, like Dryden's championship of Ben Jonson against all continental playwrights in An Essay of Dramatic Poesy, Seward's choice posed Milton as the heir of Petrarch and, indeed, centuries of Italian sonneteers. While Dryden loved Shakespeare, he recognized that contemporary French dramatists could only be challenged by a writer following classical precedents. Likewise, Milton's reputation guaranteed at least respect for his choice of poetic forms, even by notoriously stringent critics. Seward instances Boileau in a letter to T. S. Whalley in 1789, complaining that "National jealousy, and the prudery of French taste in poetry, too often made [him] unjust to the excellencies of Milton's compositions for us to believe he meant to exalt that author, when he declared the constituent excellence of the sonnet to be grave and simple energy...” ("Letter LXXVI" 2: 303). But, she concluded tartly, that quality is “...carried to its last perfection in a few of Milton's.” In an era of constant warfare against the French, the British were especially determined to uphold their national arts against those of their competitor. It no doubt gave Seward great pleasure to recognize that Milton had excelled in precisely the quality Boileau pronounced definitive, while writing not in the more lenient English rhyme pattern but in the Italian scheme. Writing within a year of the centenary of the Glorious Revolution, and as Britain anxiously monitored events in France, Seward joined her compatriots in extolling Milton not only as a champion of English liberty but also as their literary champion against continental challengers. Surely their choice of Milton's style had an array of cultural inducements besides its literary pedigree. 
The prestige accorded difficulty was important, however, especially to the many women who participated in the sonnet revival. Like Robinson, who lamented that "every romantic scribbler" thought sonnets easy to compose, Seward often remarked on the form's difficulty (9). Backscheider observes that although Smith chose the "easier" Shakespearian rhyme scheme, she elected to create a complex chain of sonnets rather than discrete examples. Backscheider believes women, conscious that their work was often trivialized by critics, consequently believed "the honor of their sex was at stake" as they worked to reinstate the sonnet (343). Competitive aggression thus partly led Seward to overlook Smith's purpose in echoing sentiments among her sonnets and to describe them, instead, as "everlasting lamentables.” What appears to us simple professional jealousy was part of a complex exercise in which women contended for prominence against other women, each anxious to claim for her poems the greatest degree of difficulty and to disparage those of her peers. "Where there is tolerable vigour of intellect," Seward boasted to Mary Knowles, "difficulty rather stimulates than discourages.” Confessing "more propensity to poetic efforts, than leisure to employ them," she added that nevertheless "we may sooner write forty lines, in any other measure, than fourteen in that of the true sonnet-but I can easier write fourteen on that arduous model, than an hundred on the easier ones" ("Letter LIV" 2: 226). The sonnet, then, suited both Seward's lack of time for composition and her genius, since, unlike other poets, she found it easier to write in the most "arduous" pattern than in any of "the easier ones." She thus used the sonnet to set herself apart from all those "who assumed the name of poet, on the slight pretense of tagging flimsy rhymes," and against whom Apollo "invented the strict, the rigorous sonnet as a test of skill” ("Letter XXXVIII" 2: 162).

Even scholars sympathetic to women poets might be tempted to dismiss Seward's vendetta against the Elegiac Sonnets as mere jealousy, or as an example of the phenomenon in which one woman wins approval from men (in this case, male critics) and is determined to prevent other women from sharing or even usurping her rewards. Her harsh comments are believed to confirm suspicions that women always behave invidiously toward one another. Only when read against the background of women's participation in the sonnet revival, as Backscheider ably describes it, can Seward's role, not as a spoiler, but as one among many women contesting for glory, be appreciated (338-51). Since Seward was already acclaimed as one of Britain's reigning poets, perhaps its chief woman poet, her adamant tone is more rather than less understandable. But because her point of view ultimately lost its cultural capital, her campaign is often described as if it were ridiculous or, at best, mystifying. When we remember that numbers of women were advancing their cases, in print, for variations of the "legitimate" or Shakespearian sonnet, Seward appears as she viewed herself, an established poet with a leading role to play in the ongoing debate. She believed in her importance not because she was delusional but because public opinion had confirmed her eminence. When she chose to side with those promoting the legitimate sonnet, she campaigned vigorously for the form apparently sanctioned by both patriotism and tradition.

Seward's pronouncements bear comparison with Pope's Dunciad. It is easy today to look back to the cultural glories of the Georgian era and laugh at Pope's expressions of despair. The introduction of Italian opera, the institution of the grand tour, the explosion of print: neither these nor any of the phenomena Pope deplores brought down the curtain on western civilization as they do at the conclusion of Pope's masterpiece. We understand, however, what Pope believed was at stake and refrain from laughing at his very public combat against modern culture. Seward 
and her fellow legitimate-sonnet advocates similarly thought British literature was being cheapened by the proliferation of a "facile form of verse" ("Letter XXXVIII" 2: 162). They sought to defend the honor of a tradition that most Britons found a source of national pride throughout the late-century years of war and empire-building. As in Pope's era, the curtain did not fall on the sonnet or on literature as a result of Smith's innovations. Instead, a burst of energy impelled British writers to initiate the literary movement that still influences our creativity. But Seward's rear-guard action on behalf of tradition is no more risible than were Pope's diatribes against Defoe, Haywood, Cibber, and other “dunces” whose writings we have learned to appreciate despite his condemnation.

Seward, moreover, proselytized on behalf of the Miltonic sonnet with the zeal of the converted. In a letter to Whalley dated April 10, 1789, she regrets their divergent "ideas of sonnetexcellence” but adds that she does not "despair of [his] conversion.” Continuing her spiritual analogy, she explains that Whalley has "a soul superior to that false shame, which annexes the idea of disgrace to changed opinions, even when their change results from the force of excellence, emerging from the mists of our accidental neglect, or hasty prejudices." She is confident that Whalley would agree with her if only, like her, he were receptive to the arguments of those with superior knowledge. She proceeds to describe her own epiphany, the result of conversations with "Mr. [Brooke] Boothby, his friend Mr. [Edward] Tighe, Mr. [Court] Dewes, and Mr. [George] Hardinge,” all "warm admirers of the best of Milton’s sonnets ... good judges of English poetry, and masters of the Italian language. Mr. Boothby and Mr. Tighe first opened my eyes ... . and I soon became of their opinion, that [the Miltonic sonnet] formed a beautiful and distinct order of composition in our language; that dignity and energetic plainness were its most indispensable characteristics.” She admits that before that exchange, she believed sonnets were characteristically light-hearted. Boothby and Tighe, however, "began my conversion” by arguing that Petrarch's sonnets were far from happy. They argued that although the word "sonnet" seemed to call for a light composition, "great writers had a just claim to have their compositions considered as models in every style in which they have excelled; that ... [Milton's] sonnets have annexed an expectation of strength and majesty to that title, which though sorrow or affectionate contemplation may soften down, the sonnet must not part with in exchange for any of the lighter graces” (“Letter LXIII” 2: 256-57).

As Laura Runge has observed, critical language throughout the long eighteenth century was gendered. Runge instances Dryden and Scott among critics who habitually used terms such as "hard," "severe," and "dignified” to describe a writer's "manly” excellence, as opposed to the "soft," "tender," and "graceful” writings they deemed feminine and of secondary value (42-43, 48-50). By convincing Seward to admire Milton's sonnets for their masculine qualities, her interlocutors likewise convinced her of the prestige of his verse and their concomitant preeminence as models. Her choice of the “dignified” style and structure over the insistent pathos of Smith's sonnets was thus a bid for recognition due to what, in their culture, was deemed excellent, namely, the manly, opposed to Smith's more "feminine" style. In her letter to Whalley, Seward does not indicate when her "conversion” to Milton's sonnet principles took place, but since Boothby and his friends were part of the Lichfield literary circle of her youth, she most likely adopted their view during her formative years as a writer. Raised to admire what her father considered the best English writers and classical translations, Seward almost inevitably 
sought to emulate the standards of those literate men who assisted her self-education (Barnard 124).

Seward's curious language of religious conversion helps explain the vehemence of her advocacy. Today, when the term "bardolatry" expresses our near-deification of Shakespeare, we must pause to remember that Milton had recently been elevated to similar status by Seward's

contemporaries. It is also helpful to recall that the Shakespearian sonnet was not the creation of Shakespeare but of the Earl of Surrey and others; we, however, continue to call it such because we consider Shakespeare to have excelled in that form. Adoring Shakespeare, we forget that to Seward and her generation, Shakespeare was a poorly educated but miraculously gifted dramatist, not a great poet. That a man with so little education would adopt the less-rigorous sonnet form would have seemed predictable but not necessarily the best precedent for a serious poet. Milton, with his vast learning and continental caché, was the preferable model. This would have been especially true for women who feared they would be judged unworthy if they chose the easier option. Such was the case for Charlotte Smith, whose sonnets attracted the scorn of other women poets concerned to distance themselves from such an unambitious "scribbler." By acquiescing in the belief of what she deemed the intelligentsia, Seward abandoned the confidence born of "long and particular study" for the dogma preached by her university-trained friends. Once converted, she adopted the rigidity of a zealot and shut her mind to the possibility of any other route to "sonnet-excellence." Having dismissed Smith's first volume, for example, she admitted in 1789 that she never saw any succeeding editions ("Letter LIII"2: 224), indicating unwillingness to reconsider her opinion or think seriously about what her contemporaries found so appealing about the Elegiac Sonnets. Perhaps, to continue the religious analogy, Seward refrained from examining any evidence that might counter her new-found belief that sonnets not constructed on the Miltonic model were inferior.

As Jane Spencer has discussed in Literary Relations, eighteenth-century women had particular difficulty inserting themselves into a literary lineage. Spencer describes the travails of women who wished to identify themselves as heirs of Dryden, for example, or Johnson, whether their predecessors were living or dead. Many cultural factors, especially the patriarchal structure of society, made it nearly impossible to claim such literary inheritances (Spencer 9-12). As the daughter of an old-fashioned man of letters who encouraged her to excel at needlework rather than writing, Seward faced literal as well as metaphorical barriers to claiming her descent from a line of writers. Milton as epic poet was not available to her as a spiritual father, but Milton the sonnet writer permitted such a claim. By championing the occasional sonnet in Petrarchan form, Seward found a way to insert herself into Milton's lineage without unduly violating feminine modesty. Like Frances Burney studying Latin under Johnson’s tutelage (Spencer 59), Seward became a happier version of Milton's daughters, composing Italianate sonnets under his aegis. The Miltonic occasional sonnet complemented Seward's gift for creating intricate, musical, and sociable verse, enhancing her chosen role as Milton’s late-century sonnet champion.

Adela Pinch has argued that Smith's method of claiming membership in a poetic lineage was through her copious allusions (62-63). Mindful of Pinch's and Spencer's observations, we might note that Smith's characteristic move was not only to claim succession but to imply superiority, as all ambitious poets must; in her case, superior suffering. A good example is the third sonnet of her collection, “To a Nightingale.” Earlier in the century, Anne Finch had made the nightingale’s 
song the subject of a witty contest between bird and poet in "To the Nightingale," which ends with the poet's frustration because, try as she might, she cannot duplicate the bird's song. Finch concludes that humans often discount or mock what they cannot equal, a statement of humility in the presence of a superior gift. Smith's sonnet takes an opposing path. As Finch had done, she interrogates the bird, but not to challenge the bird's technique. Instead, she wishes to learn the "sad cause" of its "mournful melody" (3-4). Smith yearns to translate the meaning of the bird's song, the sorrow that drives her from her nest to spend her nights singing in the woods (5-8). Smith opens her sestet speculating that the bird might once have been the victim of betrayal or even of "disastrous love" (12), now "releas'd in woodlands wild to rove" (10). Smith assumes, of course, the nightingale's legendary metamorphosis from human victim into most gifted among avian singers, privileged due to her suffering. She concludes, however, not by identifying with the bird as a fellow sufferer whose sorrows emanate in sonnets, but by envying the bird: "Ah! songstress sad! that such my lot might be, / To sigh and sing at liberty_like thee!” (13-14). Compared with Smith, the bird is actually lucky. She is "at liberty" to sing in the woods, unlike the poet, who is burdened by her human condition and, for those readers aware of Smith's plight, by her family responsibilities and legal battles. By invoking the nightingale, whose transformation occurred as a result of Philomela's rape and torture by Tereus, and then claiming superiority of woe, Smith incorporates the suggestion of sublime suffering into her sonnet. Agony worse than what was "rewarded" by eternity as a songbird must be great indeed. Smith also implies that as the nightingale's song, inspired by her former human suffering, is considered the most poignant, her sonnets, inspired by even greater suffering, must consequently be more affecting than the nightingale's. She does not claim as much, of course, but the reader might easily reach that conclusion. By claiming limitless woe, Smith claims peerless inspiration, the opposite of Finch's wryly modest conclusion in "To the Nightingale.”

Smith, in other words, accomplished by implication a version of the claim Seward made regarding Petrarch and Milton. While Seward posed as the heir of a formal tradition distinguished by rigor and gravity, Smith presented herself as heir to a tradition of singers distinguished by melancholy. From the original nightingale to Collins, Smith's was an eclectic but recognizable pedigree that included Shakespeare, Milton, and Pope in their more tender modes as well as recent poets such as Beattie and Gray. Smith emphasized her claim in the preface, explaining that "Some very melancholy moments have been beguiled, by expressing in verse the sensations those moments brought” (iii). The Elegiac Sonnets are thus about her ineffable suffering, but they are also about why Smith is a unique and splendid poet. As Backscheider observes, Smith captured the poetic mood of her generation and presented herself as the embodiment of melancholy, even as her sonnets epitomized that privileged state of mind.

Traditionalists such as Seward and Robinson found the terms of their arguments and Smith's incompatible. Proponents of the legitimate sonnet argued on behalf of formal precedents. Just as Seward refused to consider that Smith might have artful purposes in incorporating so many allusions into her sonnets, Smith refused to entertain the challenge of adopting the more rigorous form (although her third edition contained several Italian sonnets). As Seward had accepted the argument of her more educated acquaintances regarding the sonnet, Smith claims in her preface that "I am told, and I read it as the opinion of very good judges, that the legitimate Sonnet is ill calculated for our language” (iii). Eschewing the formal debate, Smith concentrated on ringing all possible changes on her theme, captivating a public accustomed to access emotions via the 
heartfelt declamations of their favorite literary characters. Both Seward and Smith were doomed to reiterate their chosen methods with no hope of a contest in their respective forms. Having determined that what Smith wrote were not sonnets, but rather "minute Elegies of twelve alternate rhymes, closing with a couplet, which assume the name of Sonnet" (Original Sonnets iii), Seward obscured the basis for meaningful comparison. All she could do was oppose her sonnets and her authorities to Smith's. Her preface quotes at length from her cousin Henry White's article in the Gentleman's Magazine, which remarked that "Mrs. Smith says she has been told that the regular Sonnet suits not the nature or genius of our language. Surely this assertion cannot be demonstrated, and therefore was not worth attention" (qtd. in Original Sonnets v). This quasi-exchange is reminiscent of those in old Western films, in which the hero challenges the villain to "come out and fight like a man." Seward and Smith fought like gentlewomen, however, sheltered behind masculine mentors.

Seward's complaints were closely related. Smith's use of a bastardized form indicated, in Seward's opinion, lack of rigor exacerbated by her copious, and in the first edition, unacknowledged, borrowings. "All the lines that are not the lines of others are weak and unimpressive," she told Sophia Weston ("Letter XXXIV”1: 162). As Pinch has explained, most of Seward's fellow readers were not disturbed by Smith's borrowings (62-63). They seem not only to have understood her intention but to have accorded her the melancholy primacy she sought. Seward responded to the perceived challenge with her own sonnets, many of which were published intermittently in the Gentleman's Magazine and other periodicals from 1785 onward. Against Smith's "pretty tuneful centos from our various poets" ("Letter XXXIV” 1: 163) she posed sonnets that resembled Milton's in possessing "certain hardnesses, though there is a majesty, perhaps, in that very hardness, which, besides producing an enchanting effect for the intermixture of the musical lines, seems to mark the peculiarity of the composition" ("Letter XLV” 1: 201). Seward's concession that Smith's lines were harmonious or melodious, but no more, with her insistence that the sonnet exhibit "certain hardnesses" as well as original thoughts and images, constituted her counter-definition of the sonnet. Although Smith's supporters praised Smith's strong and “nervous” verse, Seward denied Smith's poems those masculine, and therefore positively-gendered, qualities and strove to illustrate them in her own poems.

By "hardnesses," Seward probably meant expressions that are terse or taut as opposed to lines that flow harmoniously but are less direct. Unlike her romantic successors, Seward believed that abstract terms were acceptable when they conduced to directness. "Their nervous and condensing power seems to me peculiarly adapted to serious poetry," she explained to Erasmus Darwin in May 1789, instancing Johnson, whose "best prose" was "highly poetic, from his habit of using abstract expressions, which at once elevate his language, and compress his sense" ("Letter LXVI" 2: 267). We have noticed Seward's insistence on varied pauses resembling those in blank verse. She disdained the turn of thought characteristic of the Shakespearian sonnet, again in deference to Milton’s practice. As she insisted to Sarah Ponsonby in 1795, the

legitimate sonnet generally consists of one thought, regularly pursued to the close; ... nothing can be less necessary, indeed more improper, than a new or detached thought for the conclusion; . . . brilliance, epigrammatic turn or point, belong not to that species of composition. ... An harmonious and impressive close, provided it be not epigrammatic or detached, but connected with the subject, must be an 
advantage. Yet ... a quiet unornamented close is not inconsistent with its excellence. ("Letter XXVIII" 4: 144-45).

Since, following Milton's, superior sonnets reflect on occasional personal or communal events rather than ring changes on one (often fictional) state of mind, the witty turn calling attention to the writer's cleverness as much as to situational irony is rarely appropriate. Finally, Seward defended imperfect rhymes on the authority of "our best writers," especially Pope. Writing to Thomas Swift in 1785, she insisted "A poet will lose much more on the side of sense, and grace of expression, than he will gain on the side of jingle, by narrowing his scale of rhymes in the pursuit of imaginary perfection, which, when attained, cloys the very ear by its sameness" ("Letter XVII" 1: 72). Her choice of the Miltonic structure, with its demanding rhyme scheme, must have influenced her acceptance of imperfect rhyme, much as Pope had recourse to such rhymes (although not, as Seward claims in the same letter, "very lavishly") due to the heroic couplet's relentless demand.

Turning to Seward's Original Sonnets, we can observe how she implemented her compositional principles in contradistinction to those she perceived guiding Smith's. Sonnet XVI is her succinct version of the twenty-six lines Boileau devoted to the sonnet in The Art of Poetry. ${ }^{9}$ Boileau's late seventeenth-century treatise in alexandrine couplets, which Seward would have encountered as heroic couplets in Dryden's translation, specified that Apollo devised the sonnet as a test to learn whether ode-writers could contain their verses within strict boundaries. Apollo does not specify his rules beyond "the just Measure, and the Time, / The easy running, and alternate Rhyme," but decrees that a well-written sonnet will be worth more than "tedious Volumes of loose Poetry" (Boileau 2.83-84, 90). Boileau adds that in the volumes of a hundred scribblers, only two or three sonnets will be found worthy; the rest will be consigned to the pastry cook. Such is the difficulty of "Closing the Sense within the measur'd time" of this demanding form (2.97). Seward's version is much more dramatic, suiting her belief in the sonnet's importance. While Boileau's Apollo merely "Set rules” the Scriblers to “confound” (2.81), Seward’s god is angry:

Apollo, at his crowded altars, tir'd

Of Votaries, who for trite ideas thrown Into loose verse, assume, in lofty tone, The Poet's name, untaught, and uninspir'd, Indignant struck the Lyre.-Straight it acquir'd

New powers, and complicate. Then first was known

The rigorous Sonnet, to be fram'd alone

By duteous Bards, or by just Taste admir'd.-

Go, energetic Sonnet, go, he cried,

And be the test of skill!- For rhymes that flow

Regardless of thy rules, their destin'd guide,

Yet take thy name, ah! Let the boasters know

That with strict sway my jealous laws preside,

While I no wreaths on rebel verse bestow.

Apollo echoes Seward's remark, in her preface, dismissing "those minute Elegies ... which assume the name of Sonnet" (Original Sonnets iii). His rejection of "trite ideas thrown / into 
loose verse” seems derived not from Boileau but from Seward's opinion of Smith's "hackneyed scraps of dismality," and perhaps also from Smith's modest admission, in the preface to her first edition, that her "Sonnets, have I believe no very just claim to that title" (Elegiac Sonnets iii). Only poets willing to abide by Apollo's rules will be considered worthy, and only those with exact taste will be able to appreciate the genuine sonnet. Like Boileau, Seward does not specify the precise rules poets are to obey, but threatens with failure to attain a laurel wreath - that is, to be considered a successful poet - those who do not conform. While not so colorful an image as Boileau's threat that poor sonnets will be "shovel'd to the Pastry from the Press" (2.96), Seward's final lines create a more dignified god than the French poet's "humorous" or volatile deity (2.80).

“Sonnet XVI” illustrates Seward's principles in the guise of Apollo's. Most striking is the array of pauses: after the first three and before the last syllables in the first line; after the third syllable in the second, after the fourth in the third and fourth, after the sixth in the fifth, and so on. Running the sense from line to line, as in blank verse, Seward concludes her first sentence in the middle of line five, where Apollo's chord breaks the line while presumably calling his votaries to attention. She thus uses the caesura to create a dramatic effect while simulating the potential of blank verse for grand statements within her tightly-rhymed lines. Seward also achieves her ideal of "nervousness" or directness by using contractions. As Paul Fussell, Jr., explained, eighteenthcentury poets habitually used elisions to maintain five-syllable lines and to avoid what they thought were ugly vowel clusters. ${ }^{10}$ Although strict syllabic measure was gradually giving way to the accentual standard in Seward's lifetime (Fussell 133-56), neither she nor most of her sonnet rivals strayed far from the earlier, classically-derived ideal. In "Sonnet XVI," Seward contracts with apostrophes six words that few would pronounce as three syllables. But she also clearly intended readers to contract "Votaries" (2), "powers" (6), "rigorous" (7), and "duteous" (8). Her striking adjectival use of "complicate" instead of "complicated" in line six preserves the syllabic count while heightening the verse with a by-then nearly obsolete usage. The multiple contractions create a compactness and energy that contemporaries called "nervous." When Apollo exclaims, "Go, energetic Sonnet, go ... / And be the test of skill!” he issues a challenge while literally sending forth this illustration of his new form.

"Sonnet XVI" also fulfills Seward's ideas by developing one thought from beginning to end. Apollo's decree is not an epigram or turn but the proper conclusion of the sonnet's anecdote. As Seward reiterated, the sonnet's tone is grave and dignified, culminating in Apollo's threatening proclamation emphasizing that poets who ignore his rules are not merely poor writers and boasters but "rebels," the word italicized to emphasize the gravity of their literary crime. Rather than an amorous or light-hearted subject, this sonnet's critical topic reflects Seward's "Miltonic" preference for a serious theme. Finally, Seward carries out the relationship between Apollo's lyre and the art of poetry through the musicality of her verse. Especially striking is her use of assonance, which frequently echoes the sonnet's end rhymes. "Trite" echoes "tir'd," "Lyre" echoes "uninspired," and "boasters" echoes "flow" and "know," while within lines, "loose," "assume," and "duteous," "straight," "complicate," and "sway" create a tissue of sounds knitting together the sonnet's octave and sestet as well as its thematic purpose. The harmonious effect is heightened by consonance throughout, as when "verse" echoes "Votaries" and "rhymes," "regardless" and "rules"; the final lines gain emphasis from "strict sway" and "While ... wreaths." In her use of such effects, we see the outcome of Seward's boasted study of "the grace, 
harmony, and elegance of the English language” ("Letter XXVIII” 2: 140) as well as her conviction that the "hardnesses" characteristic of the Miltonic sonnet produce "an enchanting effect for the intermixture of the musical lines" ("Letter XLV" 1: 201).

"Sonnet XVI" is not merely a translation of Boileau, but Seward's response to Apollo's challenge. By tightening and elevating Boileau's rather informal alexandrines and casting them into sonnet form, Seward demonstrates her worthiness of Apollo's wreath, much as Pope had demonstrated his identity as the ideal poet-critic, who may "censure freely" because he has "written well," by illustrating his definitions of poor and excellent writing in An Essay on Criticism (I.240-41, lines 15-16). One wonders what Seward might have produced had she responded to Smith's achievement by composing a sonnet cycle like those through which Shakespeare, Sidney, and Spenser confirmed their ingenuity. Instead, she followed Milton's practice of writing sonnets on occasional topics, a custom also followed by Wordsworth and Keats among her better-known successors. "Sonnet XVI" suggests that Seward preferred to polish her sonnets like lapidary gems, written on a variety of thoughts and events, rather than risk diffuseness by producing numerous poems on a single theme or state of being. Seward's preference for the occasional sonnet is therefore the result of taste and principle rather than invidiousness. While it is impossible, and would in any event be inappropriate, to revisit the late eighteenth century and grant Seward the primacy she sought, her achievement in the sonnet form should be better appreciated. As Milton's champion, Seward not only contributed an exquisitely crafted body of sonnets to the form's ongoing revival: she left a challenging legacy to her Romantic-era successors. 


\section{Notes}

1. In their Introduction, Feldman and Robinson state that "Seward was the first woman sonneteer with any substantial impact upon the tradition” (10). They also state, however, that "[Charlotte] Smith and [William Lisle] Bowles set the tone for the Romantic sonnet and its emphasis on feeling” (12).

2. See, for example, McGann, Jerome. The Poetics of Sensibility: A Revolution in Literary Style. Oxford: Clarendon, 1996. 156-58. Print; Hawley, Judith. “Charlotte Smith’s Elegiac Sonnets: Losses and Gains.” Women's Poetry in the Enlightenment: The Making of a Canon, 1730-1820. Eds. Isobel Armstrong and Virginia Blain. New York: Palgrave MacMillan, 1999. 184-98. Print; Nagle, Christopher C. Sexuality and the Culture of Sensibility in the British Romantic Era. New York: Palgrave MacMillan, 2007. 50-55. Print.

3. Staves, to take one example, quotes these phrases at her study's conclusion, disagreeing with Seward's opinion but endorsing her right to criticize Smith’s writings (439).

4. Cary, Henry Francis. Sonnets and Odes. London, 1788. 5-6. Print.

5. Clifford first detailed the many inaccuracies of Seward's letters in "The Authenticity of Anna Seward's Published Correspondence.” Barnard discusses Seward’s decision to craft her letters into an autobiography in Anna Seward: A Constructed Life.

6. One thinks of the sign Bill Clinton's campaign manager, James Carville, famously placed above the candidate's desk during the 1992 presidential campaign, reminding him to repeat his chief theme: "It’s the economy, stupid!"

7. A striking example of this practice occurred in 1794, when James Boswell insulted Seward in The Gentleman's Magazine to end an ongoing, published exchange over the characterization of Samuel Johnson in his recently-published Life. In March, Seward wrote to several friends, including Henry Cary, lamenting she had no father or brother to defend her honor against Boswell but thanking them for sending letters to the $G M$ in her defense (see Seward, Letters, 3:346). That same month, her cousin Henry White published a letter supporting Seward, using some of the same phrases in Seward's letter to Cary (GM 75: 196-197).

8. Kramnick's chapter “The Cultural Logic of Late Feudalism” examines the canonization of Spenser, but many of his points apply likewise to contemporary discussions of Milton. Thomas F. Bonnell has recently disputed Kramnick's logic: since the bookselling trade was sales-driven, it would not have made sense to emphasize Milton's and Spenser's inaccessibility (22-23). Academic critics like the Wartons were concerned about corrupt texts and wished to encourage the reading of correct texts. Bonnell's point is well-taken, but for consumers like Seward, anxious to prove herself a discriminating reader and 
critic, the argument that Milton was "caviary to the general" would have increased his appeal.

9. Seward would probably have been familiar with The Art of Poetry, translated by Sir William Soames and revised by John Dryden. 10. Fussell remarks that "one of the basic aesthetic principles of conservative metric in the eighteenth century is that the poet has not only the right but the duty to improve natural phonetic materials until they become fit for elevated uses" (Theory of Prosody 75). Although the O.E.D. lists "complicate" as a synonym for intricate and complex, that use was evidently more prevalent in the seventeenth century. Poets such as Crabbe and Southey still used "complicate" in that sense, however, and Seward probably chose to do so due to the word's striking, and increasingly unusual, quality. 
Works Cited

Backscheider, Paula R. Eighteenth-Century Women Poets and Their Poetry: Inventing Agency, Inventing Genre. Baltimore: Johns Hopkins UP, 2005. Print.

Barnard, Teresa. Anna Seward: A Constructed Life. Burlington, VT: Ashgate, 2009. Print.

“Biographical Sketch of the Late Miss Seward.” The Gentleman's Magazine 79 (Apr. 1809): 378-79. Print.

Boileau, Nicolas. The Art of Poetry. Trans. Sir William Soames. Rev. by John Dryden. Glasgow : Foulis, 1755. Print.

Bonnell, Thomas F. The Most Disreputable Trade: Publishing the Classics of English Poetry, 1765-1810. Oxford: Oxford UP, 2008. Print.

Feldman, Paula, and Daniel Robinson, eds. A Century of Sonnets: The Romantic-Era Revival. Oxford: Oxford UP, 1999. Print.

Fussell, Jr., Paul. Theory of Prosody in Eighteenth-Century England. Hamden, CT: Archon, 1966. Print.

Jung, Sandro. "Susanna Pearson and the ‘Elegiac’ Lyric.” Studia Neophilologica, 78.2 (2006): 153-64. Print. http://dx.doi.org/10.1080/00393270601020823

Kramnick, Jonathan Brody. Making the English Canon: Print-Capitalism and the Cultural Past, 1700-1770. Cambridge: Cambridge UP, 1998. Print.

McCarthy, Thomas J. Relationships of Sympathy: The Writer and the Reader in British Romanticism. Aldershot, U.K.: Scolar, 1997. Print.

Pinch, Adela. Strange Fits of Passion: Epistemologies of Emotion, Hume to Austen. Stanford: Stanford UP, 1996. Print.

Pope, Alexander. An Essay on Criticism. The Poems of Alexander Pope. 10 Vols., Ed. John Butt. Oxford: Methuen, 1967. Print.

Robinson, Mary. Sappho and Phaon. 1796. Washington, D.C.: Woodstock, 2000. Print.

Runge, Laura. Gender and Language in Eighteenth-Century Literary Criticism, 1660-1790. Cambridge: Cambridge UP, 1997. Print.

Seward, Anna. “Letter LIV: Mrs. Knowles.” Seward. Vol. 2. 225-27.

---. “Letter LIII: William Hayley, Esq.” Seward. Vol. 2. 221-25. 
---. “Letter XLV: George Hardinge, Esq.” Seward. Vol. 1. 201-8.

---. “Letter XVII: Dr. S-.” Seward. Vol. 1. 70-75.

---. “Letter LXXI: Theophilus Swift, Esq.” Seward. Vol. 2. 285-88.

---. “Letter LXXVI: Rev. T.S. Whalley.” Seward. Vol. 2. 301-8.

---. “Letter LXVI: Dr. Darwin.” Seward. Vol. 2. 263-70.

---. “Letter LXIII: Rev. T.S. Whalley.” Seward. Vol. 2. 255-60.

---. "Letter XXXVIII: Rev. - Berwick.” Seward. Vol. 2. 161-66.

---. “Letter XXXIV: To Miss Weston.” Seward. Vol. 1. 162-66.

---. “Letter XXVIII: George Hardinge, Esq.” Seward. Vol. 2. 139-41.

---. “Letter XXVIII: Miss Ponsonby.” Seward. Vol. 4. 142-48.

---. Letters of Anna Seward: Written between the Years 1784 and 1807. 6 vols. Edinburgh: Ramsay, 1811. Print.

---. Original Sonnets on Various Subjects, and Odes Paraphrased from Horace. London, 1799. Print.

Smith, Charlotte. Elegiac Sonnets. London, 1789. Print.

Spencer, Jane. Literary Relations: Kinship and the Canon, 1660-1830. Oxford: Oxford UP, 2005. Print.

Staves, Susan, A Literary History of Women's Writing in Britain, 1660-1789. Cambridge: Cambridge UP, 2006. Print. http://dx.doi.org/10.1017/CBO9780511484513

Wood, Gillen D’Arcy. “The Female Penseroso: Anna Seward, Sociable Poetry, and the Handelian Consensus.” Modern Language Quarterly 67.4 (Dec. 2006): 451-77. Print. http://dx.doi.org/10.1215/00267929-2006-012 